\section{Tomato Growth in Spring-sown Cover Crops}

\author{
Mary C. Akemo ${ }^{1}$, Mark A. Bennett ${ }^{2}$, and Emilie E. Regnier ${ }^{3}$ \\ Department of Horticulture and Crop Science, Kottman Hall, 2021 Coffey \\ Road, Ohio State University, Columbus, OH 43210
}

Additional index words. Lycopersicon esculentum, legume/monocot mixtures, winter rye, field peas, undercutting, allelochemicals, tropical climates

\begin{abstract}
Pure and biculture stands of rye 'Wheeler' (Secale cereale L.) and field pea (Pisum sativum L.) were established and killed for mulch in Spring 1996, 1997, and 1998, in Columbus, Ohio. Treatments were five rye to pea proportions, each with a high, medium, and low seeding rate. Their effects on tomato (Lycopersicon esculentum Mill.) growth and yield were compared with those of a weedy check; a tilled, nonweeded check; and a tilled, hand-weeded check. Tomato tissue and soil were sampled for nutrient analysis. Number of leaves, branching, height, leaf area, dry weight, rate of flowering and fruit set, and fruit yield of tomato plants varied directly with the proportion of pea in the cover crop and decreased with reduced cover crop seeding rates. In 1997, yields of tomato were as high as $50 \mathrm{MT} \cdot \mathrm{ha}^{-1}$ in the 1 rye : 3 pea cover crop; yield was poorest in the weedy check $\left(0.02 \mathrm{MT} \cdot \mathrm{ha}^{-1}\right.$ in 1996). Most of the cover-cropped plots produced better yields than did the conventionally weeded check. No consistent relationship between levels of macronutrients in tomato leaf and soil samples and the cover crop treatments was established. Spring-sown rye + pea bicultures (with a higher ratio of pea) have a potential for use in tomato production.
\end{abstract}

In developing countries, vegetables are produced with very low levels, if any, of agricultural chemicals. Most farmers rely on the innate fertility of the land and invest considerable labor in land preparation and weed control. Yields from vegetable and other crops are much lower than those obtained by farmers in developed countries, where considerable off-farm inputs are used. Intensive land use has reduced productivity and environmental quality, and low cost and low-input production methods are needed to maintain and, if

Received for publication 8 Mar. 1999. Accepted for publication 16 July 1999. Salaries and research support provided by state and federal funds appropriated to the Ohio Agricultural Research and Development Center (OARDC), The Ohio State Univ. Manuscript Number 99-3. This paper is a portion of a dissertation submitted by M.C. Akemo in partial fulfillment of $\mathrm{PhD}$ requirements at Ohio State Univ. We thank E. Grassbaugh, M. Schmittgen, K. DeWeese, and J. Warren for research assistance; B. Bishop for statistical assistance; and Moore Seed Farm for providing the rye seed used in this study. The research was supported by the Government of Uganda, the Ohio State Univ. I.P.M. Program, and the Ohio Vegetable and Small Fruit Research and Development Program. Mention of a trademark, proprietary product, or vendor does not constitute a guarantee or warranty of the product and does not imply its approval to the exclusion of other products or vendors that also may be suitable. The cost of publishing this paper was defrayed in part by the payment of page charges. Under postal regulations, this paper therefore must be hereby marked advertisement solely to indicate this fact.

${ }^{1}$ Former Ohio State Univ. Graduate Student, currently Research Scientist at the Kawanda Agr. Res. Inst. P.O. Box 7065, Kampala, Uganda.

${ }^{2}$ Professor. To whom reprint requests should be addressed. E-mail address: bennett.18@osu.edu ${ }^{3}$ Associate Professor. possible, improve soil productivity and crop yields while reducing production costs. Cover crop use is one potential method to achieve these goals.

Some studies involving overwintered cover crops for vegetable production in temperate climates have yielded positive results (Abdul-Baki and Teasdale, 1993; NeSmith et al., 1994). A few studies have shown the possibility of using cover crops sown in the spring for weed control, but not all reported the effect on the primary crops (Ateh and Doll, 1996; Barnes and Putnam, 1983; Bordelon and Weller, 1997; Nelson et al., 1991). This raised our interest in exploring cover crop use for crop production in tropical climates while taking into account some pertinent differences. One possible option for the tropics would be to sow the cover crops at the beginning of the rainy season, kill them 1.5 to 2 months later, then establish the vegetable crops.

Primary crops may be negatively affected by cover crops, many of which produce allelochemicals that suppress weeds (Creamer et al., 1996; Lehle et al., 1983; Putnam, 1988; White et al., 1989). Allelopathic cover crop extracts can effect both weed and primary crop seed germination and seedling growth (Lehle et al., 1983; White et al., 1989). Cover crops could also deplete soil nutrients and soil moisture, thus limiting their availability to the subsequent primary crops.

Plant mulches delayed tomato fruit maturity by $\approx 10 \mathrm{~d}$, but total yield in a hairy vetch mulch was more than twice that of the nonmulched control, or of plants mulched with black polyethylene (Abdul-Baki and Teasdale, 1993). Potential cover crops have to be assessed for their effect on primary crop growth and yield before they are recommended to farmers (Creamer et al., 1997). Research based upon developing country conditions has to be conducted to determine the effect of cover crops on the establishment, growth, and eventual yield of vegetable crops.

The use of legume/monocot cover crop combinations could result in greater vegetable crop yields than using pure legume or monocot stands, because the two cover crop families have several complementary characteristics (Mohler and Teasdale, 1993; Walker, 1993). Legumes fix and add $\mathrm{N}$ to the soil, while monocots could offset the rapid decomposition of legumes. Leaching of $\mathrm{N}$ is also less in legume/monocot mixtures than in a pure legume stand (Agboola and Fayemi, 1972; Clark et al., 1994; Sainju and Singh, 1997). With the right legume/monocot cover crop combination, the vegetable crop would benefit from both weed control and $\mathrm{N}$ fixation.

To simulate establishing a cover crop at the onset of the rains in a tropical situation, we evaluated how a tomato crop would perform in cover crops sown in the early spring and killed prior to its establishment. The specific objectives were to 1) determine the effect of rye: pea cover crop proportions and seeding rates on the subsequent performance of a tomato crop in the field, and 2) determine the effect of the different cover crop treatments on soil fertility before and after the crop trial.

\section{Materials and Methods}

Field trials were conducted in 1996, 1997, and 1998 at The Ohio State Univ. Waterman Agricultural and Natural Resources Farm in Columbus, on a Miami silt loam (Mesic Typic Hapludalf) soil. To maximize the weed pressure and in keeping with minimizing the use of agricultural chemicals, the field plots chosen for the trials were not treated with herbicides. The land was disc plowed and then rototilled to obtain a fine seedbed. Flat seedbeds measuring $2.5 \times 7.5 \mathrm{~m}$ were used in 1996, while raised beds measuring $1.2 \times 12 \mathrm{~m}$ were used in 1997 and 1998. Cover crops winter rye (Secale cereale L. 'Wheeler') and field peas (Pisum sativum L.) were sown by hand and raked in on 18 Apr. 1996, 24 Apr. 1997, and 23 Apr. 1998. Cover crop proportions and seeding rates are shown in Table 1. A randomized complete-block design was used with four replications. Each year, actual seeding rates were adjusted using germination percentages of pea and rye determined prior to sowing the cover crops.

The tomato cultivar Marglobe from the Ohio Seed Co. (West Jefferson, Ohio) was used as the test vegetable crop. After weed observations (percentage of ground cover, weed density, weed shoot biomass) were taken (Akemo et al., 2000), the cover crops and the weedy nontilled (WNT) check were mowed down $74 \mathrm{~d}$ after planting (DAP) in 1996 and undercut 61 DAP and 63 DAP in 1997 and 1998, respectively (Creamer et al., 1995). Cover crop biomass was also determined just prior to killing the rye and pea treatments (Akemo et al., 2000). The weedy tilled (WT) and the weed-free tilled (WFT) checks were 
cultivated 83, 61, and 73 DAP in 1996, 1997. and 1998, respectively. One-month-old tomato seedlings were hand-transplanted on 11 and 12 July 1996, 26 and 27 June 1997, and 6 and 7 July 1998. Seedlings were planted in three rows/plot with 15 plants/row spaced 75 $\mathrm{cm}$ between rows in 1996. Spacing in 1997 and 1998 was $60 \mathrm{~cm}$ between rows and $45 \mathrm{~cm}$ between plants, with 50 plants/row and two rows/raised bed. Plant spacing within the row was $45 \mathrm{~cm}$ in all 3 years. Each seedling received $200 \mathrm{~mL}$ of $10 \mathrm{~N}-22.9 \mathrm{P}-8.3 \mathrm{~K}$ Plantex starter solution (PlantCo., Brampton, Ont., Canada) at transplanting. No other fertilizer amendments were made in the trial plots for the duration of the experiments.

Pest management decisions were based on scouting and university recommendations (Precheur, 1998). To gauge the effect of the different cover crop treatments on growth, tomato plants were destructively harvested from all treatments $31 \mathrm{~d}$ after transplanting (DAT) in 1996, 34 DAT in 1997, and 50 DAT in 1998 . Growth was very slow in 1998 because of low soil moisture and high weed pressure. Spring and Summer 1996 and 1998 were drier than in 1997 (data not shown), and the tomatoes had to be watered with overhead sprinkler irrigation about five times after transplanting. Summer 1998 was especially dry after transplanting and severely affected the establishment of the transplants. No supplemental irrigation was necessary in 1997. The youngest fully expanded leaflets

Table 1. Cover crop and seeding rates used in 1996, 1997, and 1998 field trials in Columbus, Ohio.

\begin{tabular}{|c|c|c|c|c|}
\hline \multirow[b]{2}{*}{ Cover crop } & \multirow[b]{2}{*}{ Ratio (rye : peas) } & \multirow[b]{2}{*}{ Seeding rate ${ }^{z}$} & \multicolumn{2}{|c|}{ Seeding rate $\left(\mathrm{kg} \cdot \mathrm{ha}^{-1}\right)$} \\
\hline & & & Rye & Pea \\
\hline \multirow[t]{3}{*}{ Rye } & $1: 0$ & High & 114.0 & \\
\hline & & Medium & 57.0 & \\
\hline & & Low & 28.5 & \\
\hline \multirow[t]{9}{*}{ Rye/field peas } & $3: 1$ & High & 85.5 & 35.5 \\
\hline & & Medium & 42.8 & 17.8 \\
\hline & & Low & 21.4 & 8.9 \\
\hline & $1: 1$ & High & 57.0 & 71.0 \\
\hline & & Medium & 28.5 & 35.5 \\
\hline & & Low & 14.3 & 17.8 \\
\hline & $1: 3$ & High & 28.5 & 106.5 \\
\hline & & Medium & 14.3 & 53.3 \\
\hline & & Low & 7.1 & 26.6 \\
\hline \multirow[t]{3}{*}{ Field peas } & $0: 1$ & High & & 142.0 \\
\hline & & Medium & & 71.0 \\
\hline & & Low & & 35.5 \\
\hline Weedy not tilled (WNT) & & WNT & & \\
\hline Weedy tilled (WT) & & WT & & \\
\hline Weed-free tilled (WFT) & & WFT & & \\
\hline
\end{tabular}

${ }^{2}$ High, medium, and low are $100 \%, 50 \%$, and $25 \%$ seeding rates, respectively. No cover crops were sown in the controls WNT, WT, and WFT. from the top of the tomato canopy were picked for tissue nutrient analysis 33 DAT in 1996 and 53 DAT in 1997. Data were collected on flowering, fruiting, and fruit ripening. The WFT treatment was handweeded whenever required. Ten plants were tagged for harvesting from the central row of each plot in 1996 and from the central parts of both rows in 1997 and 1998. Tomato fruit were harvested and weighed as they ripened to breaker stage at 4-7 d harvest intervals. Soil was sampled before sowing cover crops and at the end of the growing season in 1997 and 1998 for nutrient analysis at OARDC labs. Soil was also sampled at time of tomato transplanting in 1998.

Data were analyzed using SAS (PROC GLM) (SAS Institute, 1990) and significantly different means of main factors were separated by least significant difference (LSD). Interactions of years, cover crop proportions, and seeding rates were tested for significance and appropriate tables were constructed according to the significant interactions.

\section{Results and Discussion}

Tomato plant growth and development. Tomato plant growth was greater in 1997 than in 1996 and 1998 (Table 2). There were more leaves per plant in 1997 than in 1996 and 1998 (Table 2), and the number increased significantly with increasing pea proportions in the cover crops in 1996. The year $\times$ cover crop interaction was significant for all vegetative growth parameters except plant height.

The year $\times$ cover crop interaction also significantly affected branching. Tomato plants in WT and WFT had the most branches in 1996 and 1998 (data not shown). In 1996, branching

Table 2. Main effects and interactions of rye: pea ratio and seeding rates in cover crop on tomato leaf and branch numbers, and tomato plant height over 3 years of field studies.

\begin{tabular}{|c|c|c|c|c|c|c|c|}
\hline \multirow[b]{2}{*}{ Treatment } & \multicolumn{2}{|c|}{1996 (no./plant) } & \multicolumn{2}{|c|}{1997 (no./plant) } & \multicolumn{2}{|c|}{1998 (no./plant) } & \multirow{2}{*}{$\begin{array}{c}\text { 1996-98 (pooled) } \\
\mathrm{Ht}(\mathrm{cm})\end{array}$} \\
\hline & Leaves & Branches & Leaves & Branches & Leaves & Branches & \\
\hline \multicolumn{8}{|c|}{ Cover crop } \\
\hline Rye & $11 b^{z}$ & $1 \mathrm{~b}$ & 44 & 4 & 6 & 0 & $45.4 \mathrm{c}$ \\
\hline 3 rye : 1 pea & $8 \mathrm{~b}$ & $2 a b$ & 35 & 3 & 7 & 0 & $47.7 \mathrm{bc}$ \\
\hline 1 rye : 1 pea & $26 \mathrm{ab}$ & $4 \mathrm{a}$ & 39 & 3 & 7 & 0 & $51.5 \mathrm{ab}$ \\
\hline 1 rye : 3 pea & $37 \mathrm{a}$ & $5 \mathrm{a}$ & 49 & 4 & 8 & 0 & $52.6 \mathrm{a}$ \\
\hline Pea & $35 \mathrm{a}$ & 5 a & 48 & 4 & 10 & 1 & $55.6 \mathrm{a}$ \\
\hline \multicolumn{8}{|c|}{ Seeding rates ${ }^{y}$} \\
\hline High & 31 & 4 & 41 & 3 & 9 & 0 & $53.0 \mathrm{a}$ \\
\hline Medium & 26 & 3 & 48 & 3 & 8 & 1 & $50.8 \mathrm{ab}$ \\
\hline Low & 19 & 2 & 39 & 4 & 6 & 0 & $47.8 \mathrm{~b}$ \\
\hline \multicolumn{8}{|c|}{ Year } \\
\hline 1996 & & & & & & & $49.5 \mathrm{~b}$ \\
\hline 1997 & & & & & & & $67.8 \mathrm{a}$ \\
\hline 1998 & & & & & & & $34.4 \mathrm{c}$ \\
\hline \multicolumn{8}{|c|}{ Interaction } \\
\hline Cover crop (CC) & $* * *$ & $*$ & NS & NS & NS & NS & $* * *$ \\
\hline Seeding rate (SR) & NS & NS & NS & NS & NS & NS & $*$ \\
\hline $\mathrm{CC} \times \mathrm{SR}$ & NS & NS & NS & NS & NS & NS & NS \\
\hline Year (Y) & & & & & & & $* * *$ \\
\hline $\mathrm{Y} \times \mathrm{CC}$ & & & & & & & NS \\
\hline $\mathrm{Y} \times \mathrm{SR}$ & & & & & & & NS \\
\hline $\mathrm{Y} \times \mathrm{CC} \times \mathrm{SR}$ & & & & & & & NS \\
\hline
\end{tabular}

${ }^{2}$ Mean separation within columns and main effects by LSD at $P \leq 0.05$. All other effects nonsignificant.

${ }^{y} \mathrm{High}$, medium, and low equal $100 \%, 50 \%$ and $25 \%$ seeding rates, respectively.

Ns, ${ }^{*}, *, * * *$ Nonsignificant at $P \leq 0.05,0.01,0.001$, respectively, by analysis of variance. 
increased with increasing proportions of field peas in the cover crop mix (Table 2). Tomato plants in cover-cropped treatments branched most in 1997, and least in 1998.

Tomato plant heights pooled over the 3 years varied inversely with the proportions of rye in the cover crops, and directly with seeding rate (Table 2).

Tomato leaf area generally increased with increasing field pea ratios in the cover crop and decreased with decreasing seeding rate (Table 3 ), and the year $\times$ cover crop interaction was significant. Only in 1997 did tomato plants in the controls (WT and WFT) have smaller leaf areas than those in some of the covercropped treatments (Table 3). Mean leaf areas recorded in 1997 were more than twice those in 1996, and more than 15 times those in 1998 (Table 3).

Dry weights of tomato plants in covercropped treatments and WNT were much lower in 1998 than in 1996 and 1997 (Table 3) because of extremely dry conditions and weed pressure. In 1996, tomato plants in WT, pure rye (high), and 1 rye : 3 pea (high) plots were heavier than those in the weed-free tilled control (WFT). Tomato plants in WT and WFT were heavier than all the other treatments in 1998. Tomato dry weights increased with increasing proportions of pea in cover crop combinations in all 3 years, and fell with reducing seeding rate in 1996 and 1998 (Table 3 ). There were significant differences in tomato dry weights among treatment and seeding rate pooled over the 3 years. Tomato plants grew better with higher proportions of pea, possibly because of $\mathrm{N}$ fixed by legumes being available in the soil. At higher cover crop seeding rates, weeds were suppressed more than at lower rates (Akemo et al., 2000), resulting in greater tomato growth and yield.

Tomato flowering and fruit set. Flowering started 24 DAT in 1996, 25 DAT in 1997 (Fig. 1), and 35 DAT in 1998. Plants flowered later in pure rye in 1996 (Fig. 1A), but in 1997 the higher and constant soil moisture helped in overcoming the stunting effect of rye (Fig. 1B). By 5 Sept. 1996, <60\% of the plants had bloomed in rye at high and medium rates, while by 26 Aug. 1997 in rye (high) to 3 rye : 1 pea (medium), $90 \%$ or more of the tomato plants had flowered. Fifty percent flowering was achieved earliest by tomato plants in 1 rye : 3 pea and pea at high rate, WT, and WFT in 1996, and in 3 rye : 1 pea, 1 rye : 1 pea, 1 rye : 3 pea at high rate in 1997 (Fig. 1B). Tomato plants in WNT were the slowest to flower in both years, achieving $\leq 20 \%$ by 5 Sept. 1996 . Flowering was very poor in 1998 in the cover-cropped treatments, with the controls WT and WFT outperforming those in all treatments (data not shown). Tomato plants in all cover-cropped plots and WNT achieved $<20 \%$ flowering. The presence of peas in the cover crop mulch appeared to partially overcome the effects of unfavorable weather and weed pressure.

Tomato fruit set followed a similar pattern to that of flowering (Akemo, 1998) with plants in 3 rye : 1 pea, and pea at high rates plus WT, and WFT achieving 50\% fruiting earlier than

Table 3. Effects of cover crop and seeding rate on leaf area and dry weight of tomato plants 1 month after transplanting in 1996 and 1997, and 2 months after transplanting in 1998.

\begin{tabular}{|c|c|c|c|c|c|c|c|}
\hline \multirow[b]{2}{*}{$\begin{array}{l}\text { Cover crop ratio } \\
\text { (Rye/peas) }\end{array}$} & \multirow[b]{2}{*}{$\begin{array}{l}\text { Seeding } \\
\text { rate }^{z}\end{array}$} & \multicolumn{2}{|c|}{1996} & \multicolumn{2}{|c|}{1997} & \multicolumn{2}{|c|}{1998} \\
\hline & & $\begin{array}{l}\text { Leaf area } \\
\left(\mathrm{cm}^{2} / \text { plant }\right)\end{array}$ & $\begin{array}{l}\text { Dry wt } \\
\text { (g/plant) }\end{array}$ & $\begin{array}{c}\text { Leaf area } \\
\left(\mathrm{cm}^{2} / \text { plant }\right)\end{array}$ & $\begin{array}{l}\text { Dry wt } \\
\text { (g/plant) }\end{array}$ & $\begin{array}{c}\text { Leaf area } \\
\left(\mathrm{cm}^{2} / \text { plant }\right)\end{array}$ & $\begin{array}{l}\text { Dry wt } \\
\text { (g/plant) }\end{array}$ \\
\hline $1: 0$ & --- & $166 \mathrm{c}^{\mathrm{y}}$ & $2.9 \mathrm{c}$ & $1041 \mathrm{c}$ & $12.5 \mathrm{bc}$ & 50 & 0.9 \\
\hline $3: 1$ & --- & $301 \mathrm{c}$ & $5.0 \mathrm{bc}$ & $806 \mathrm{c}$ & $10.4 \mathrm{c}$ & 58 & 1.0 \\
\hline $1: 1$ & --- & $510 \mathrm{bc}$ & $8.4 \mathrm{ab}$ & $1157 \mathrm{bc}$ & $13.9 \mathrm{ab}$ & 57 & 1.0 \\
\hline $1: 3$ & --- & $787 \mathrm{ab}$ & $11.1 \mathrm{a}$ & $1427 \mathrm{ab}$ & $15.8 \mathrm{ab}$ & 90 & 1.6 \\
\hline $0: 1$ & --- & 949 a & $13.4 \mathrm{a}$ & $1513 \mathrm{a}$ & $16.5 \mathrm{a}$ & 120 & 2.0 \\
\hline --- & High & $801 \mathrm{a}$ & $11.5 \mathrm{a}$ & 1289 & 14.6 & $101 \mathrm{a}$ & $1.8 \mathrm{a}$ \\
\hline --- & Medium & $494 \mathrm{ab}$ & $7.5 \mathrm{ab}$ & 1169 & 13.9 & $79 a b$ & $1.3 \mathrm{ab}$ \\
\hline --- & Low & $332 \mathrm{~b}$ & $5.5 \mathrm{~b}$ & 1109 & 13.0 & $45 \mathrm{~b}$ & $0.7 \mathrm{~b}$ \\
\hline \multicolumn{8}{|c|}{ Controls } \\
\hline $\mathrm{WNT}^{\mathrm{x}}$ & & $127 \mathrm{~b}$ & $2.5 \mathrm{~b}$ & $561 \mathrm{~b}$ & $6.4 \mathrm{~b}$ & $50 \mathrm{c}$ & $0.7 \mathrm{c}$ \\
\hline WT & & $1870 \mathrm{a}$ & $23.5 \mathrm{a}$ & $1182 \mathrm{a}$ & $13.8 \mathrm{a}$ & $857 \mathrm{~b}$ & $23.8 \mathrm{~b}$ \\
\hline WFT & & 2041 a & $16.6 \mathrm{a}$ & $1181 \mathrm{a}$ & $12.9 \mathrm{a}$ & 3159 a & $52.9 \mathrm{a}$ \\
\hline \multicolumn{8}{|c|}{ Interactions } \\
\hline Cover crop (CC) & & $* *$ & $* * *$ & $* * *$ & $* *$ & NS & NS \\
\hline Seeding rate (SR) & & $*$ & $*$ & NS & NS & $*$ & $*$ \\
\hline $\mathrm{CC} \times \mathrm{SR}$ & & NS & NS & NS & NS & NS & NS \\
\hline
\end{tabular}

${ }^{\mathrm{z}}$ High, medium and low equal $100 \%, 50 \%$, and $25 \%$ seeding rates, respectively.

${ }^{y}$ Mean separation within columns and main effects by LSD at $P \leq 0.05$. All other effects are ns. ${ }^{\mathrm{x}} \mathrm{WNT}=$ weedy not tilled; WT $=$ weedy tilled; WFT $=$ weed-free checks.

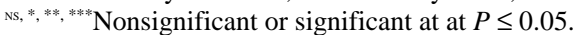

the other treatments in 1996 and 1997. Among cover-cropped treatments, fruit set was delayed in pure rye treatments in 1996, but not in 1997. In 1997, adequate soil moisture, together with less weed pressure (Akemo et al., 2000), overcame the suppressive effect of the rye on the tomato crop. The tilled plots fruited later than some of the cover-cropped plots in 1997, but not in 1996 and 1998. Fruiting of tomato plants in the weedy, nontilled plots was delayed most in 1996 and 1997. Fruiting of tomato plants in 1998 was much delayed in cover-cropped treatments and weedy, nontilled plots, while fruiting in tilled plots was comparable with that in 1996 and 1997.

In 1997, tomato fruit ripening was earliest in 3 rye : 1 pea and 1 rye : 1 pea at high rate, and WFT plots (Fig. 2). Five d later, fruit ripening in pure rye and pure pea at medium rates had accelerated compared to other treatments. Despite earlier flowering and fruiting in pure rye at high rate, fruit ripening in pure rye (high), 1 rye : 1 pea (low), 3 rye : 1 pea (medium) and WNT was very late. AbdulBaki and Teasdale (1993) reported that plant mulches delayed tomato fruit maturity by $\approx 10 \mathrm{~d}$ compared with black polyethylene mulch. In our study, the weedy, tilled plots (WT) were comparable with the slower ripening, cover-cropped treatments, while the weedfree tilled checks (WFT) were comparable with the earlier and faster-ripening covercropped treatments.

At the time young tomato leaves were collected for nutrient analysis in 1996 and 1997, flowering and some fruit set had occurred in most of the treatments. The only significant differences were among $P$ levels of cover crop combinations (pure rye treatments had lower P values) and $\mathrm{K}$ levels for seeding rates (low rate treatments had lower $\mathrm{K}$ values) in 1996 (Akemo, 1998). Contrary to our expectations, increasing the proportion of pea in the cover crop had no effect on $\mathrm{N}$ level in tomato leaves.
Tomato fruit yield. Among cover-cropped treatments 1 rye : 3 pea and pure pea at high rates had the most fruits in all 3 years (Table 4 ). The WNT plots had the least number of fruits while WFT plots had the most. Both cover crop proportion and seeding rate effects were significant with fruit numbers increasing from 3 rye : 1 pea to pure pea, and decreasing with decreasing cover crop seeding rates (Table 4$)$. Numbers of fruits differed $(P \leq 0.01)$ among years, with mean numbers recorded in 1997 being 43 times those in 1998 . Year $\times$ seeding rate interaction was significant.

The greatest fruit weights in cover cropped treatments were recorded in 1 rye : 1 pea, 1 rye : 3 pea, pure pea (all at high rates), and pure pea (low rate) in 1996, while in 1998 highest yields followed 1 rye : 1 pea, 1 rye : 3 pea, and pure pea at high rates. Yields in 1997 ranged from $13 \mathrm{MT} \cdot \mathrm{ha}^{-1}$ in the weedy check to $52 \mathrm{MT} \cdot \mathrm{ha}^{-1}$ in 1 rye : 1 pea (high) and were less variable than for 1996 or 1998 (Table 4). Cover crop proportion and seeding rate significantly affected fruit weight pooled over years, with yields increasing from pure rye to pure pea, and falling with decreasing seeding rate (Table 4). Differences among years were highly significant with yields in 1997 being 35 times those in 1998. Interactions between year, cover crop proportion, and seeding rate were nonsignificant (Table 4).

Mean tomato yield over the 3 years was positively correlated with pea dry weight (Fig. 3B), and was negatively, but very weakly, affected by rye dry weight (Fig. 3C), thus the stronger correlation obtained for total cover crop biomass resulted from the presence of field peas.

There were no significant differences in soil pH, CEC, and macronutrient levels among treatments in 1997 (Akemo, 1998). However, soil $\mathrm{P}$ and $\mathrm{K}$ levels were higher in all treatments at the end of the growing season. This is not easily explained for the WNT, WT, and WFT treatments. All Ca, Mg, and CEC levels 


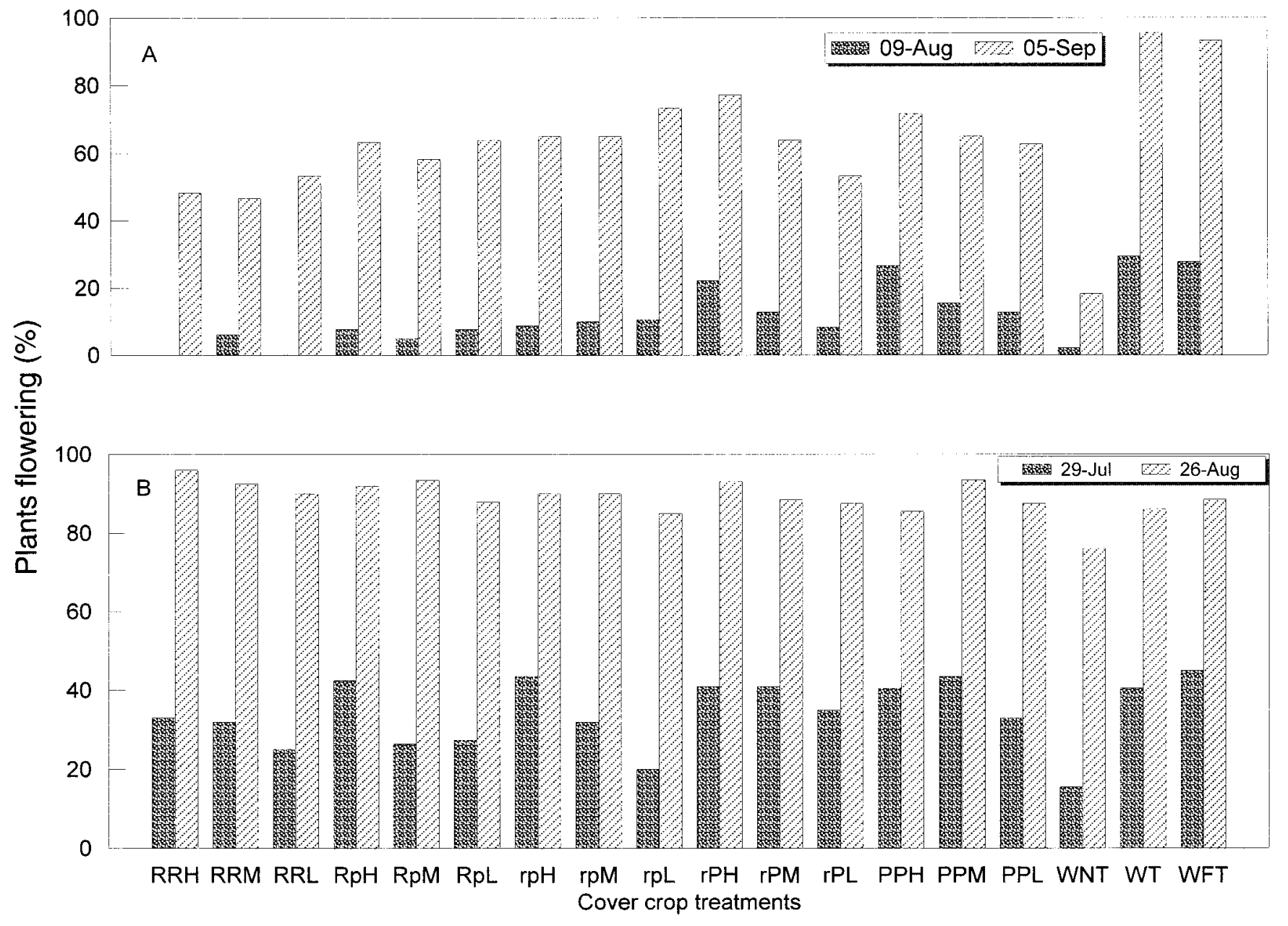

Fig. 1. Effect of cover crop treatments on rate of flowering of tomato plants in (A) 1996 and (B) 1997. The treatments were RR (pure rye), Rp (3 rye :1 pea), rp (1 rye : 1 pea), rP (1 rye : 3 pea), and PP (pure pea). H, M, and L = 100\%, 50\%, and 25\% seeding rates, respectively. WNT (weedy not tilled), WT (weedy tilled), and WFT (weed-free tilled checks).

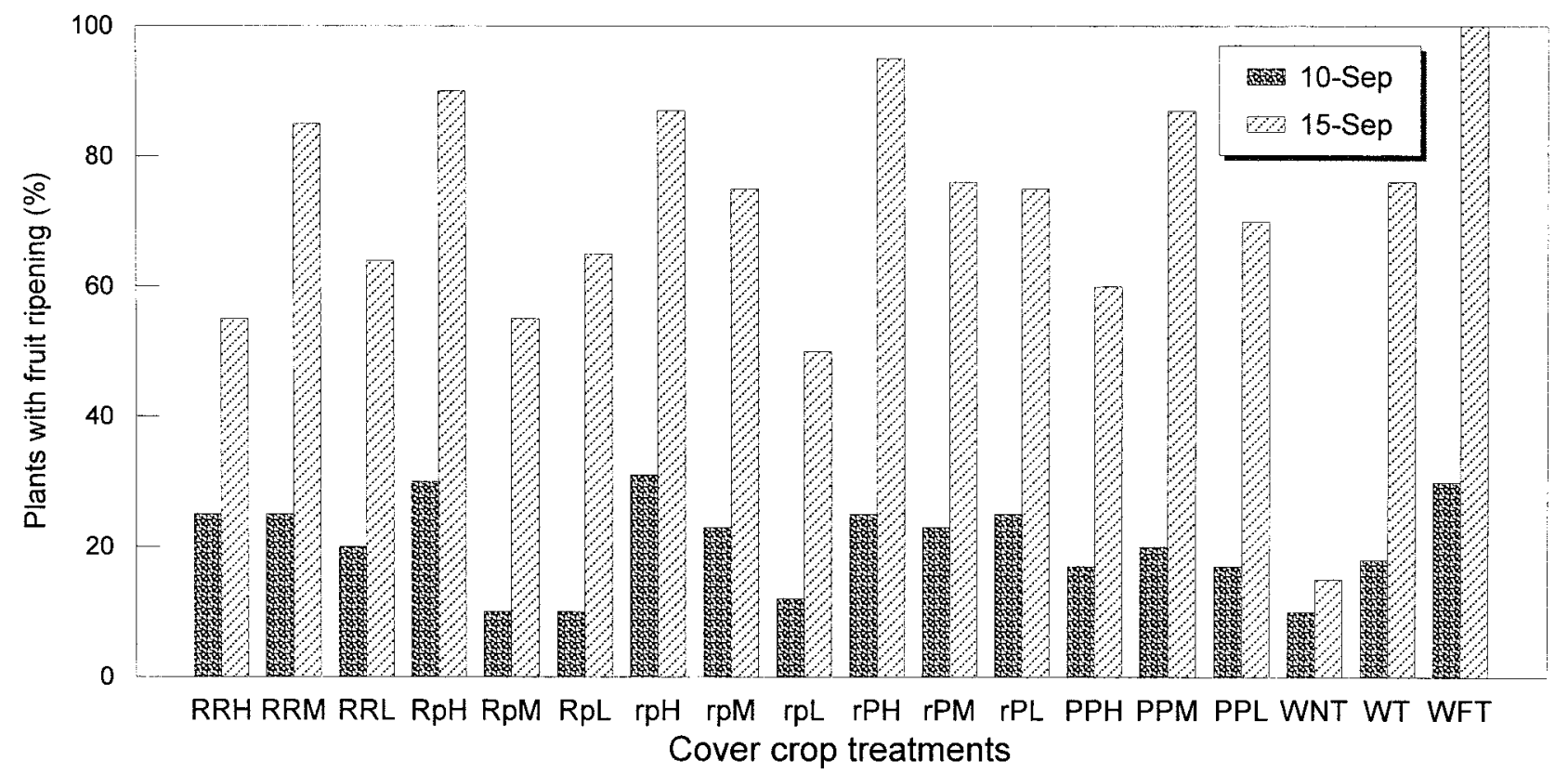

Fig. 2. Effect of cover crop treatments on rate of ripening of tomato fruit in 1997 . The treatments were RR (pure rye), Rp ( 3 rye : 1 pea), rp ( 1 rye : 1 pea), $\mathrm{rP}$ (1 rye : 3 pea), and $\mathrm{PP}$ (pure pea). $\mathrm{H}, \mathrm{M}$, and $\mathrm{L}=100 \%, 50 \%$, and $35 \%$ seeding rates, respectively. WNT (weedy not tilled), WT (weedy tilled), and WFT (weed-free tilled checks). 
Table 4. Main effects and interactions of rye : pea ratios and seeding rates on fruit number and tomato fruit yield for 1996, 1997, and 1998 in Columbus.

\begin{tabular}{|c|c|c|c|c|c|c|c|c|}
\hline \multirow[b]{3}{*}{ Treatment } & \multirow{2}{*}{\multicolumn{3}{|c|}{ No. fruit/plant }} & \multirow{2}{*}{\multicolumn{3}{|c|}{ Fruit yield $\left(\mathrm{MT} \cdot \mathrm{ha}^{-1}\right)$}} & \multicolumn{2}{|c|}{ 1996-98 } \\
\hline & & & & & & & \multirow{2}{*}{$\begin{array}{c}\text { No. } \\
\text { fruit/plant }\end{array}$} & \multirow{2}{*}{$\begin{array}{l}\text { Avg. fruit yield } \\
\left(\mathrm{MT} \cdot \mathrm{ha}^{-1}\right)\end{array}$} \\
\hline & 1996 & 1997 & 1998 & 1996 & 1997 & 1998 & & \\
\hline \multicolumn{9}{|c|}{ Cover crop $(C C)$} \\
\hline Rye & $8 b^{z}$ & 128 & 2 & $0.7 \mathrm{c}$ & 36.9 & 1.9 & $46 \mathrm{bc}$ & $13.2 \mathrm{~b}$ \\
\hline 3 rye $: 1$ pea & $13 \mathrm{~b}$ & 117 & 2 & $2.0 \mathrm{bc}$ & 36.5 & 0.6 & $44 \mathrm{c}$ & $13.1 \mathrm{~b}$ \\
\hline 1 rye $: 1$ pea & $22 \mathrm{ab}$ & 128 & 3 & $3.9 \mathrm{abc}$ & 39.9 & 1.1 & $50 \mathrm{abc}$ & $14.9 \mathrm{ab}$ \\
\hline 1 rye : 3 pea & $29 \mathrm{a}$ & 135 & 3 & $6.8 \mathrm{ab}$ & 43.9 & 1.2 & $55 \mathrm{ab}$ & $17.3 \mathrm{a}$ \\
\hline Pea & $30 \mathrm{a}$ & 139 & 3 & $8.4 \mathrm{a}$ & 45.1 & 0.8 & $57 \mathrm{a}$ & $18.1 \mathrm{a}$ \\
\hline \multicolumn{9}{|c|}{ Seeding rates $(S R)^{y}$} \\
\hline High & $31 \mathrm{a}$ & $143 \mathrm{a}$ & $4 \mathrm{a}$ & $7.7 \mathrm{a}$ & 42.7 & $2.0 \mathrm{a}$ & $59 a$ & $17.5 \mathrm{a}$ \\
\hline Medium & $16 \mathrm{~b}$ & $133 \mathrm{a}$ & $2 a b$ & $2.6 \mathrm{~b}$ & 41.1 & $0.8 \mathrm{~b}$ & $50 \mathrm{~b}$ & $14.8 \mathrm{~b}$ \\
\hline Low & $14 \mathrm{~b}$ & $109 \mathrm{~b}$ & $1 \mathrm{~b}$ & $2.9 \mathrm{~b}$ & 37.6 & $0.5 \mathrm{~b}$ & $42 \mathrm{c}$ & $13.7 \mathrm{~b}$ \\
\hline \multicolumn{9}{|c|}{ Controls } \\
\hline WNT $^{\mathrm{x}}$ & $<1 \mathrm{c}$ & $26 \mathrm{c}$ & $0 \mathrm{c}$ & $<1 \mathrm{c}$ & $13.2 \mathrm{c}$ & $<1 \mathrm{c}$ & $9 \mathrm{c}$ & $4.5 \mathrm{c}$ \\
\hline WT & $83 \mathrm{~b}$ & $97 \mathrm{~b}$ & $43 \mathrm{~b}$ & $21.3 \mathrm{~b}$ & $31.6 \mathrm{~b}$ & $9.5 \mathrm{~b}$ & $74 \mathrm{~b}$ & $22.3 \mathrm{~b}$ \\
\hline WFT & $111 \mathrm{a}$ & $158 \mathrm{a}$ & $92 \mathrm{a}$ & $34.0 \mathrm{a}$ & $50.0 \mathrm{a}$ & $31.4 \mathrm{a}$ & $120 \mathrm{a}$ & $38.5 \mathrm{a}$ \\
\hline \multicolumn{9}{|c|}{$\operatorname{Year}(Y)$} \\
\hline 1996 & --- & --- & --- & --- & --- & --- & $20 \mathrm{~b}$ & $4.4 \mathrm{~b}$ \\
\hline 1997 & --- & --- & --- & --- & --- & --- & $129 \mathrm{a}$ & $40.5 \mathrm{a}$ \\
\hline 1998 & --- & --- & --- & --- & --- & --- & $3 \mathrm{c}$ & $1.1 \mathrm{c}$ \\
\hline \multicolumn{9}{|c|}{ Interactions } \\
\hline $\mathrm{CC}$ & $* \mathrm{w}$ & NS & NS & $*$ & NS & NS & $*$ & $* *$ \\
\hline SR & $* *$ & $* *$ & $*$ & $*$ & NS & $*$ & $* * *$ & $* *$ \\
\hline $\begin{array}{l}\mathrm{CC} \times \mathrm{SR} \\
\text { Year }\end{array}$ & NS & NS & NS & NS & NS & NS & $\begin{array}{l}\text { NS } \\
* * *\end{array}$ & $\begin{array}{l}\text { NS } \\
* * *\end{array}$ \\
\hline $\mathrm{Y} \times \mathrm{CC}$ & & & & & & & NS & NS \\
\hline $\mathrm{Y} \times \mathrm{SR}$ & & & & & & & $* *$ & NS \\
\hline $\mathrm{Y} \times \mathrm{CC} \times \mathrm{SR}$ & & & & & & & NS & NS \\
\hline
\end{tabular}

${ }^{2}$ Mean separation within columns and main effects by LSD at $P \leq 0.05$. All other effects nonsignificant. ${ }^{\mathrm{y}} \mathrm{High}$, medium, and low equal $100 \%, 50 \%$, and $25 \%$ seeding rates, respectively.

${ }^{\mathrm{x}} \mathrm{WNT}=$ weedy not tilled; $\mathrm{WT}=$ weedy tilled; $\mathrm{WFT}=$ weed-free checks.

Ns, *,**,**** Nonsignificant or significant at $P \leq 0.05,0.01,0.001$, respectively, by analysis of variance.
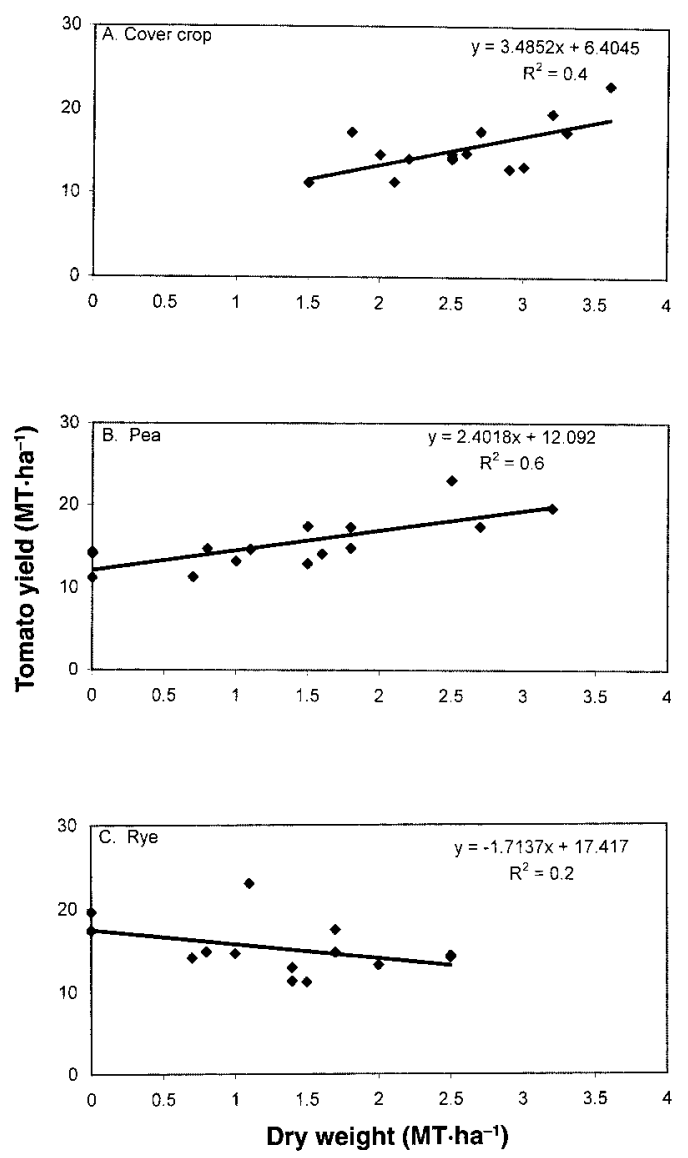

Fig. 3. Influence of (A) total cover crop, (B) pea aboveground biomass, and (C) rye aboveground biomass on tomato fruit yield pooled over years. were lower in end-of-season soil samples. In 1998 N, P, K, Ca, Mg, and CEC levels were higher in all treatments at cover crop kill than at the end of the season, with no significant differences among all 18 treatments. End-ofseason $\mathrm{N}$ levels were lower in all treatments except 1 rye : 3 pea (high rate), indicating that $\mathrm{N}$ was probably utilized during the season by the dense weed population. Since study locations were shifted each year at the research farm, we were unable to draw conclusions on the cumulative effect of cover crops on soil nutrients in this study.

Overall, adequate soil moisture tended to overcome the suppressive effect of weed pressure and rye on tomato growth and yield. Tomato plants grew faster, became larger, and yielded more fruit in 1997, when there was much more rainfall, than in 1996 and 1998. Supplementary irrigation in 1996 and 1998 was infrequent and uneven, not providing enough moisture for normal growth. Under limited precipitation and high weed pressure, the presence of field peas in the mulch promoted growth and development of tomato plants in comparison with those in rye mulch. Generally, as the ratio of field peas to rye increased, leaf number, branching, plant height, leaf area, and dry weight of tomato plants increased. Fruit yield was positively correlated with field pea biomass. The higher the field pea ratio in the cover crop biculture, the greater the amount of $\mathrm{N}$ fixed, which should translate into better tomato plant growth. The highest yields of tomato were recorded following the highest seeding rates of 1 rye : 1 pea, 1 rye : 3 pea, and pure pea cover crops.

\section{Literature Cited}

Abdul-Baki, A.A. and J.R. Teasdale. 1993. A notillage tomato production system using hairy vetch and subterranean clover mulches. HortScience 28:106-108.

Agboola, A.A. and A.A. Fayemi. 1972. Fixation and excretion of $\mathrm{N}$ by tropical legumes. Agron. J. 64:409-412.

Akemo, M.C. 1998. An exploration of cover crops for vegetable production systems in tropical situations. PhD Diss., Ohio State Univ., Columbus.

Akemo, M.C., E.E. Regnier, and M.A. Bennett. 2000. Effect of rye-pea proportion and seeding rate on early weed control by spring-sown cover crops. Weed Technol. (In press.).

Ateh, C.M. and J.D. Doll. 1996. Spring-planted winter rye (Secale cereale) as a living mulch to control weeds in soybean (Glycine max). Weed Technol. 10:347-353.

Barnes, J.P. and A.R. Putnam. 1983. Rye residues contribute weed suppression in no-tillage cropping systems. J. Chem. Ecol. 9:1045-1057.

Bordelon, B.P. and S.C. Weller. 1997. Preplant cover crops affect weed and vine growth in first year vineyards. HortScience 32:1040-1043.

Clark, A.J., A.M. Decker, and J.J. Meisinger. 1994. Seeding rate and kill date effects on hairy vetch-cereal rye cover crop mixtures for corn production. Agron. J. 86:1065-1070.

Creamer, N.G. and M.A. Bennett. 1997. Evaluation of cover crop mixtures for use in vegetable production systems. HortScience 32:866-870.

Creamer N.G., M.A. Bennett, B.R. Stinner, J. Cardina, and E.E. Regnier. 1996. Mechanisms 
of weed suppression in cover crop-based production systems. HortScience 31:410-413.

Creamer, N.G., B. Plassman, M.A. Bennett, R.K. Wood, B.R. Stinner, and J. Cardina. 1995. A method for mechanically killing cover crops to optimize weed suppression. Amer. J. Alt. Agr. 10:156-161.

Lehle, F.R., R. Frans, and M. McClelland. 1983. Allelopathic potential of Hope white lupine (Lupinus albus) herbage and herbage extracts. Weed Sci. 31:513-519.

Mohler, C.L. and J.R. Teasdale. 1993. Response of weed emergence to rate of Vicia villosa Roth and Secale cereale L. residues. Weed Res. 33:487-499.
Nelson, W.A., B.A. Kahn, and B.W. Roberts. 1991 Screening cover crops for use in conservation tillage following spring plowing. HortScience 26:860-862.

NeSmith,D.S., G.Hoogeboom, andD.V.McCracken. 1994. Summer squash production using conservation tillage. HortScience 29:28-30.

Precheur, R.J. 1998. Ohio vegetable production guide: Bul. 674. Ohio State Univ. Ext., Columbus.

Putnam, A.R. 1998. Allelopathy: Problems and opportunities in weed management, p. 77-86. In: M.A. Altieri and M. Liebman (eds.). Weed management in agroecosystems: Ecological approaches. CRC Press, Boca Raton, Fla.
Sainju, U.M. and B.P. Singh. 1997. Winter cover crops for sustainable agricultural systems: Influence on soil properties, water quality, and crop yields. HortScience 32:21-26.

SAS Institute. 1990. SAS/STAT user's guide: Vers. $6,4^{\text {th }}$ ed. SAS Inst., Cary, N.C.

Walker, J.L. 1993. The improvement of tropical pastures: Introduction, p. 3-4. In: R.L. Burt, P.P. Rotar, J.L. Walker, and M.W. Silvey (eds.). The role of Centrosema, Desmodium, and Stylosanthes in improving tropical pastures. Westview Press, Boulder, Colo.

White, R.H., A.D. Worsham, and U. Blum. 1989. Allelopathic potential of legume debris and aqueous extracts. Weed Sci. 37:674-679. 